\title{
A new virus isolated from cultured grass carp Ctenopharyngodon idella
}

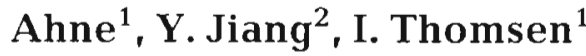 \\ ${ }^{1}$ Institute of Zoology and Hydrobiology of The University of Munich, D-8000 Munich, Federal Republic of Germany \\ ${ }^{2}$ Institute of Hydrobiology, Academia Sinica, Wuhan, People's Republic of China
}

\begin{abstract}
A virus isolated from normal-appearing grass carp (Ctenopharyngodon idella Valenciennes, 1844) multiplied in fish cells (CAR and CLC cells) at 15 to $25^{\circ} \mathrm{C}$ producing syncytia followed by lysis. The agent was inactivated by treatment with acid $(\mathrm{pH} 3)$, heat $\left(56^{\circ} \mathrm{C}\right)$, and chloroform $(50 \%)$. Human type 0 erythrocytes were not hemagglutinated $\left(\mathrm{pH} 7.2,20^{\circ} \mathrm{C}\right)$. Treatment with 5 -iodo-2deoxyuridine did not affect viral replication, indicating an RNA genome. Electron microscopy of infectious tissue culture fluid revealed rod-shaped particles measuring 170 to $220 \times 50$ to $55 \mathrm{~nm}$.
\end{abstract}

\section{INTRODUCTION}

During recent years, production of plant-eating fishes, especially the grass carp, has steadily increased worldwide. As a result grass carp have become established outside their native range in East Asia because of their weed control capacity in aquaculture. However, viruses, bacteria, fungi, and a certain number of parasites cause considerable debilitation and mortality in grass carp.

The introduction of this foreign species therefore carries the risk of spreading pathogens to native fish fauna. The cestode Bothriocephalus gowkongensis represents an example of a major pathogen introduced to Europe with grass carp from the Far East. The most serious disease affecting cultured grass carp in China is a hemorrhagic virus disease caused by a reovirus (Chen \& Jiang 1984). The agent infects grass carp of all ages and kills about $80 \%$ of the fingerlings. Additionally, a rhabdovirus has been isolated from grass carp in Europe that showed pathological signs similar to the hemorrhagic virus disease (Ahne 1975). However, the 2 agents are morphologically and serologically distinct.

In June 1986, a previously unknown virus was isolated from healthy looking 2 yr old grass carp imported into Germany from Hungary. In this paper we describe some properties of the new agent which is provisionally designated as CIVH 33/86 (Ctenopharyngodon idella virus Hungary $33 / 86$ ).

\section{MATERIALS AND METHODS}

Isolation trials. Samples of liver, spleen, and kidney of healthy 2 yr old grass carp were ground in a mortar and diluted $1: 10$ in TC 199 medium containing $2 \%$ fetal calf serum, $1000 \mathrm{IU}$ penicillin $\mathrm{ml}^{-1}$ and $1000 \mu \mathrm{g}$ streptomycin $\mathrm{ml}^{-1}$. After centrifugation at $2000 \times \mathrm{g} ; 10-$ fold diluted supernatant fluid was inoculated into monolayers of several fish cell lines. Inoculated cell cultures were incubated at $20^{\circ} \mathrm{C}$.

Cell lines. Gonad cells of rainbow trout Salmo gairdneri (RTG-2), embryo cells of chinook salmon Oncorhynchus tschawytscha (CHSE-214), caudal trunk cells of blue-gill fry Lepomis macrochitus (BF-2), caudal trunk cells of fathead minnow Pimephales promelas (FHM), fin cells of goldfish Carassius auratus (CAR), gonad cells of pike Esox Iucius (PG), leucocytes of common carp Cyprinus carpio (CLC), and liver cells of rainbow trout Salmo gairdneri (R-1) were used. The cells were grown at 15 and $20^{\circ} \mathrm{C}$ in TC 199 medium containing Earl's salts, $10 \%$ fetal bovine serum, 100 IU penicillin $\mathrm{ml}^{-1}$, and $100 \mu \mathrm{g}$ streptomycin $\mathrm{ml}^{-1}$.

Titration of virus. Titration of virus was done by the $50 \%$ end-point dilution ( $\mathrm{TCID}_{50}$ ) method in CAR cells grown in microculture at $25^{\circ} \mathrm{C}$. Infectivity of virus was calculated by the method of Reed \& Muench (1938).

Biochemical and biophysical characterization of virus. To determine if the virus possessed a lipid- 
containing envelope, infectious culture medium, freed of cell debris by centrifugation $(3000 \times \mathrm{g}, 10 \mathrm{~min})$, was mixed with an equal volume of chloroform. After mixing the 2 phases, they were kept for $12 \mathrm{~h}$ at $4{ }^{\circ} \mathrm{C}$. The aqueous phase was than separated by centifugation $(3000 \times \mathrm{g}, 10 \mathrm{~min})$, diluted in 10 -fold steps, and the dilutions inoculated onto CAR cells. Controls, treated in the same way, were culture medium without virus.

The effect of 5-iododeoxyuridine (IUdR) on viral replication was determined by the method of Rovozzo \& Burke (1973). Monolayers of CAR cells in multiwellplates were treated with $50 \mu \mathrm{g} I U d R \mathrm{ml}^{-1}$ for $12 \mathrm{~h}$. Afterwards, the cultures were titrated for their virus content using the TCID 50 method. Frog virus 3 , a DNA virus, served as the positive control; infectious pancreatic necrosis virus, an RNA virus, served as the negative control.

To determine if the agent was sensitive to heat, virus in the culture medium was titrated after exposure to $56^{\circ} \mathrm{C}$ for 30,60 , and $120 \mathrm{~min}$.

The effect of low $\mathrm{pH}$ on the virus was determined by adjusting the infectious cell culture medium to $\mathrm{pH} 3$ using PBS-HCl. After 30, 60, and 120 min reaction time, samples were neutralized with $0.1 \mathrm{~N} \mathrm{NaOH}$. The infectivity of samples before and after treatment was titrated.

The stability of virus to freezing and thawing was analysed by freezing infectious cell culture medium at $-20^{\circ} \mathrm{C}, 6$ times. Samples were then titrated in CAR cells by the $\mathrm{TCID}_{50}$ method.

To identify the nucleic acid type of the virus, CAR cells grown in Leighton tubes were infected with a multiplicity of infection (MOI) of 1 . After $36 \mathrm{~h}$ incubation at $25^{\circ} \mathrm{C}$, the cells were fixed with Carnoy fixative and stained with $0.01 \%$ acridine orange in Mcllvaine buffer.

To determine the morphology of the virus, pellets obtained by centrifuging $(85000 \times \mathrm{g}, 2 \mathrm{~h})$ infectious cell culture fluid were resuspended, stained with $1 \%$ phosphotunstic acid, and examined by electron microscopy using a Zeiss EM 109.

Biological characterization of virus. Neutralization of infectivity of the isolate by antisera against the fish rhabdoviruses Rhabdovirus anguilla strain X (EVX), virus of hemorrhagic septicemia (VHS), infectious hematopoietic necrosis virus (IHNV), pike fry rhabdovirus (PFR), and spring viremia of carp virus (SVCV) was carried out as described by Ahne (1981).

To determine the hemagglutinating activities of the virus, infectious tissue culture medium (freed of cells) was reacted with human type 0 red blood cells as described by Rovozzo \& Burke (1973). An orthomyxovirus (Ahne et al. in press) served as the positive control.

To investigate the susceptibility of cell lines to the virus, RTG-2, CHSE-214, BF-2, FHM, CAR, PG, CLC, and R-1 cells were infected with a MOl of 1 . After $7 \mathrm{~d}$ at $25^{\circ} \mathrm{C}$, flasks were frozen at $-20^{\circ} \mathrm{C}$, thawed, and the medium titrated by the $\mathrm{TCID}_{50}$ method.

The optimum temperature for virus replication was determined using cultures of CAR cells grown in $25 \mathrm{~cm}^{2}$ flasks. The cells, infected with an MOI of 1 . were incubated at $10,15,20,25$, and $28^{\circ} \mathrm{C}$. At Days 1 , $2,3,4,5$, and 6 , infected cell cultures were frozen at $-20^{\circ} \mathrm{C}$, thawed, and the cell-free medium titrated by the TCID 50 method.

A single-cycle growth curve of the isolate was carried out in CAR cells at $20^{\circ} \mathrm{C}$. Cells infected with a MOI of 1 (adsorption method) were frozen $\left(-20^{\circ} \mathrm{C}\right)$ at intervals of $1,2,4,6,8,12,24,36,48,60,72,84,96$, and $120 \mathrm{~h}$ after infection. Samples were titrated by the $\mathrm{TCID}_{50}$ method.

\section{RESULTS}

\section{Multiplication of virus in vitro}

The CAR, CLC, and FHM cells, infected at $25^{\circ} \mathrm{C}$, showed extensive cytopathogenic effects (CPE) consisting of cell fusion followed by lysis. In Giemsastained CAR cells, numerous syncytia were present (Figs. $1 \& 2$ ). Destruction of cells by the virus followed 24 to $48 \mathrm{~h}$ after infection. In BF-2, PG, and RTG-2 cells, CPE were moderate. However, CHSE-214 and R1 cells proved to be refractory.

Replication of the virus in CAR, CLC, and FHM cells resulted in titres ranging from 5.8 to $7.8 \log _{10} \mathrm{TCID}_{50}$ $\mathrm{ml}^{-1}$ after $7 \mathrm{~d}$ incubation at $20^{\circ} \mathrm{C}$. Titres obtained in BF-2, PG, and RTG-2 cells were between 3.5 and 1.5 $\log _{10} \mathrm{TCID}_{50} \mathrm{ml}^{-1}$ (Table 1). Optimal replication of virus in CAR cells was between 20 and $25^{\circ} \mathrm{C}$. Peak titres occurred at $48 \mathrm{~h}$ after infection at $25^{\circ} \mathrm{C}$ and at $96 \mathrm{~h}$ at $20^{\circ} \mathrm{C}$. At $15^{\circ} \mathrm{C}$, the agent showed only minimal growth. No virus replication was detected at 10 and $28^{\circ} \mathrm{C}$.

First progeny virus was synthesized in CAR cells within 10 to $12 \mathrm{~h}$ at $20^{\circ} \mathrm{C}$. Both cell-associated and cellfree virus reached titres above $7 \log _{10} \mathrm{TCID}_{50} \mathrm{ml}^{-1} 48 \mathrm{~h}$ after infection.

\section{Biochemical and biophysical characterization of the isolate}

The virus proved to be labile to chloroform, $\mathrm{pH} 3$, and heat. Virus replication was not inhibited by IUdR; freezing and thawing reduced the infectivity of the agent less than 10 -fold. The results, summarized in Table 2, indicate that the isolate possesses a RNA genome and a lipid-containing envelope. 


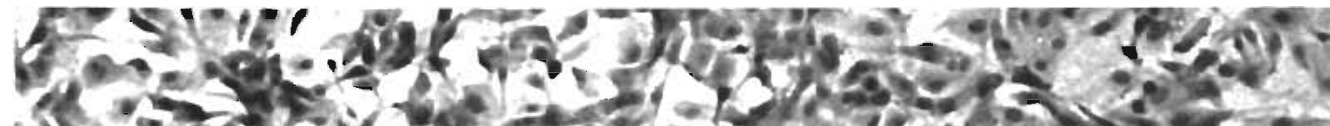
IS

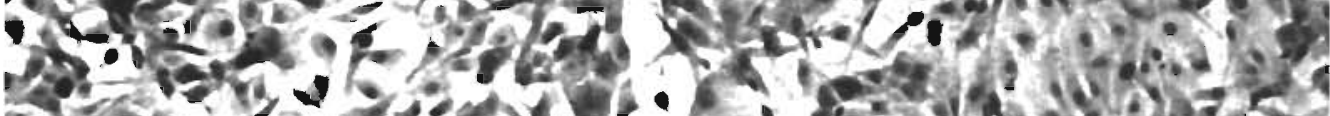

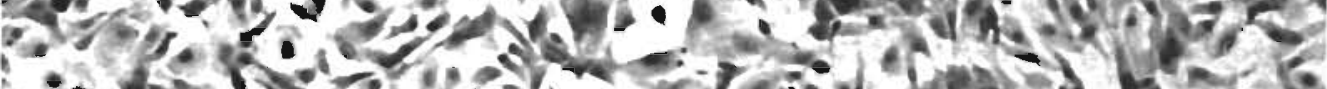
s.

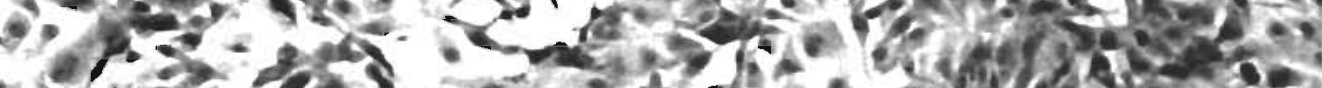

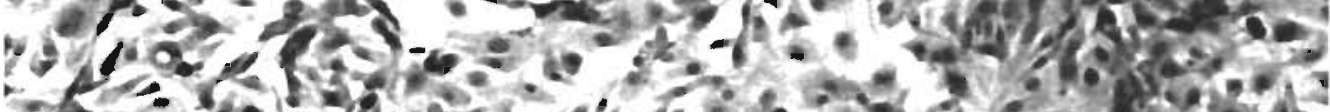

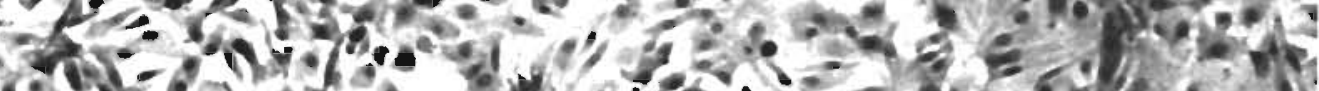

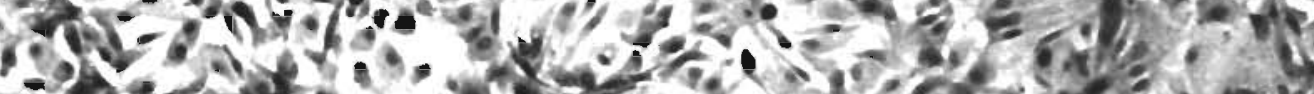

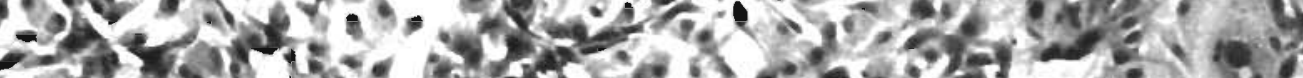
$37 \%$.

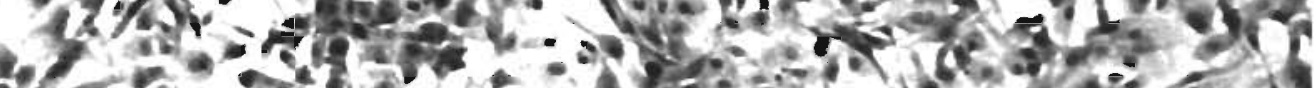

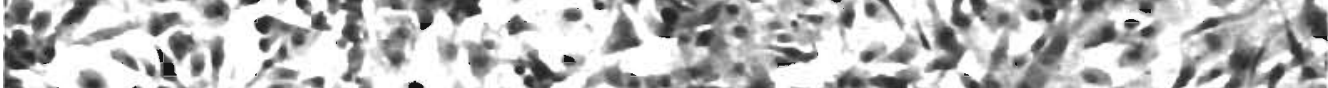

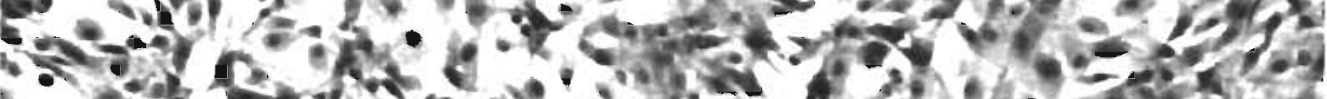

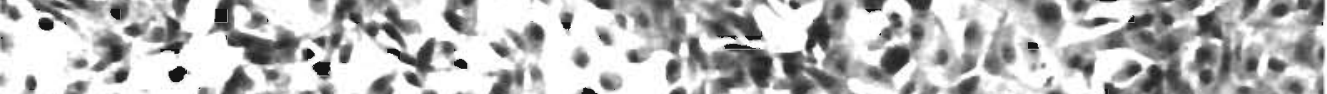

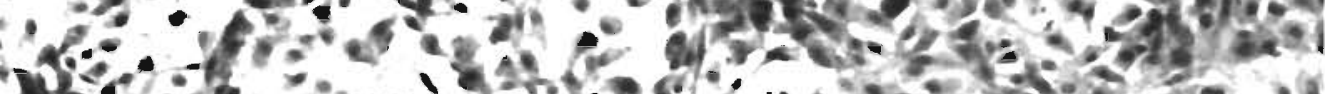

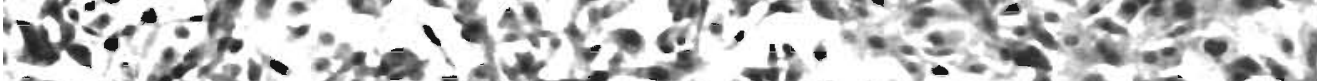

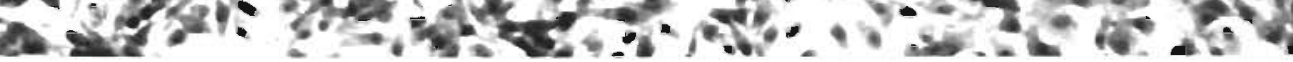

Fig. 1. Uninfected, Giemsa-stained goldfish fin (CAR) cells. $60 x$

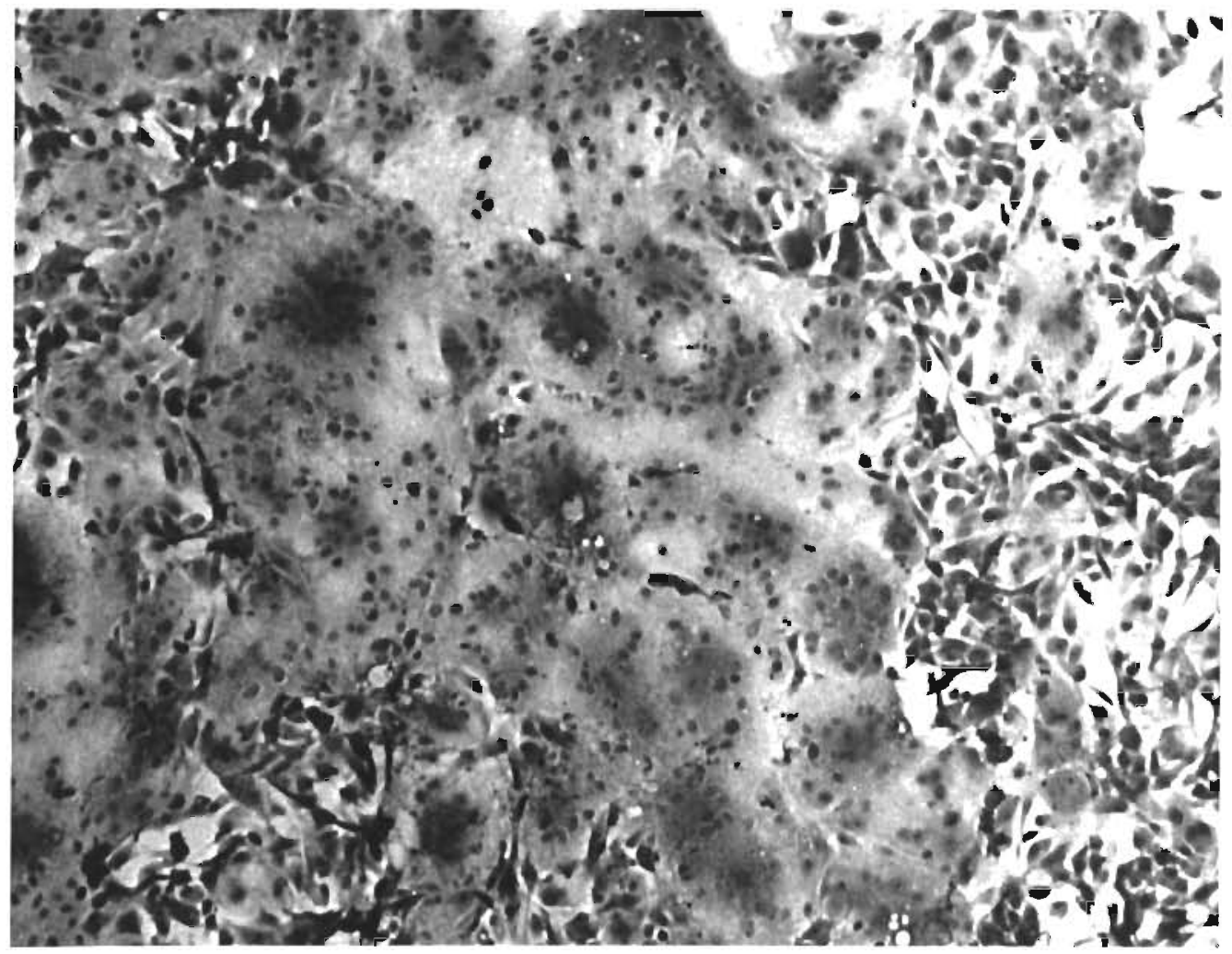

Fig. 2. Giemsa-stained CAR cells $24 \mathrm{~h}$ after infection with isolate CIH 33/86. Numerous syncytia are present. $60 \times$ 
Table 1. Susceptibility of 8 fish cell lines to the isolate. CPE: cytopathogenic effects

\begin{tabular}{lcr|}
\hline Cell line & TCID $_{50} \mathrm{ml}^{-1}$ & CPE \\
\hline CAR & $10^{7.8}$ & ++++ \\
CLC & $10^{6.8}$ & +++ \\
FHM & $10^{5.8}$ & ++ \\
BF-2 & $10^{35}$ & + \\
PG & $10^{25}$ & + \\
RTG-2 & $10^{15}$ & + \\
R1 & 0 & - \\
CHSE 214 & 0 & - \\
\hline
\end{tabular}

After treatment with acridine orange, infected CAR cells exhibited red-stained cytoplasm, indicating the presence of a single-stranded viral RNA.

The isolate was not neutralized by antisera to the fish rhabdoviruses EVX, VHS, IHNV, PFR, and SVCV. In contrast, the neutralization index (NI) of the homologous serum was $3 \log _{10}$.

The isolate did not hemagglutinate human type 0 red
Table 2. Biochemical and biophysical properties of the isolate

\begin{tabular}{|c|c|c|}
\hline \multirow[t]{2}{*}{ Treatment } & \multicolumn{2}{|c|}{$\mathrm{TCID}_{50} \mathrm{ml}^{-1}$} \\
\hline & $\begin{array}{l}\text { Before } \\
\text { treatment }\end{array}$ & $\begin{array}{l}\text { After } \\
\text { treatment }\end{array}$ \\
\hline Chloroform $(50 \%)$ & $10^{5.8}$ & 0 \\
\hline $\operatorname{IUdR} \quad\left(50 \mu \mathrm{g} \mathrm{ml}^{-1}\right)$ & $10^{6.2}$ & $10^{6.5}$ \\
\hline (30 min) & $10^{6,2}$ & $10^{20}$ \\
\hline$(120 \mathrm{~min})$ & $10^{62}$ & 0 \\
\hline (30 min) & $10^{62}$ & 0 \\
\hline \multicolumn{3}{|l|}{ Freezing/thawing } \\
\hline 3 times & $10^{62}$ & $10^{5.8}$ \\
\hline 6 times & $10^{62}$ & $10^{4.5}$ \\
\hline
\end{tabular}

blood cells whereas the control orthomyxovirus (Ahne et al. in press) showed hemagglutination titers up to $1: 128$.

In negatively stained preparations, rod-shaped particles measuring 170 to $220 \mathrm{~nm}$ in length and 50 to 55 $\mathrm{nm}$ in width were seen using the electron microscope (Fig. 3a). An envelope could clearly be detected on some particles (Fig. 3b).

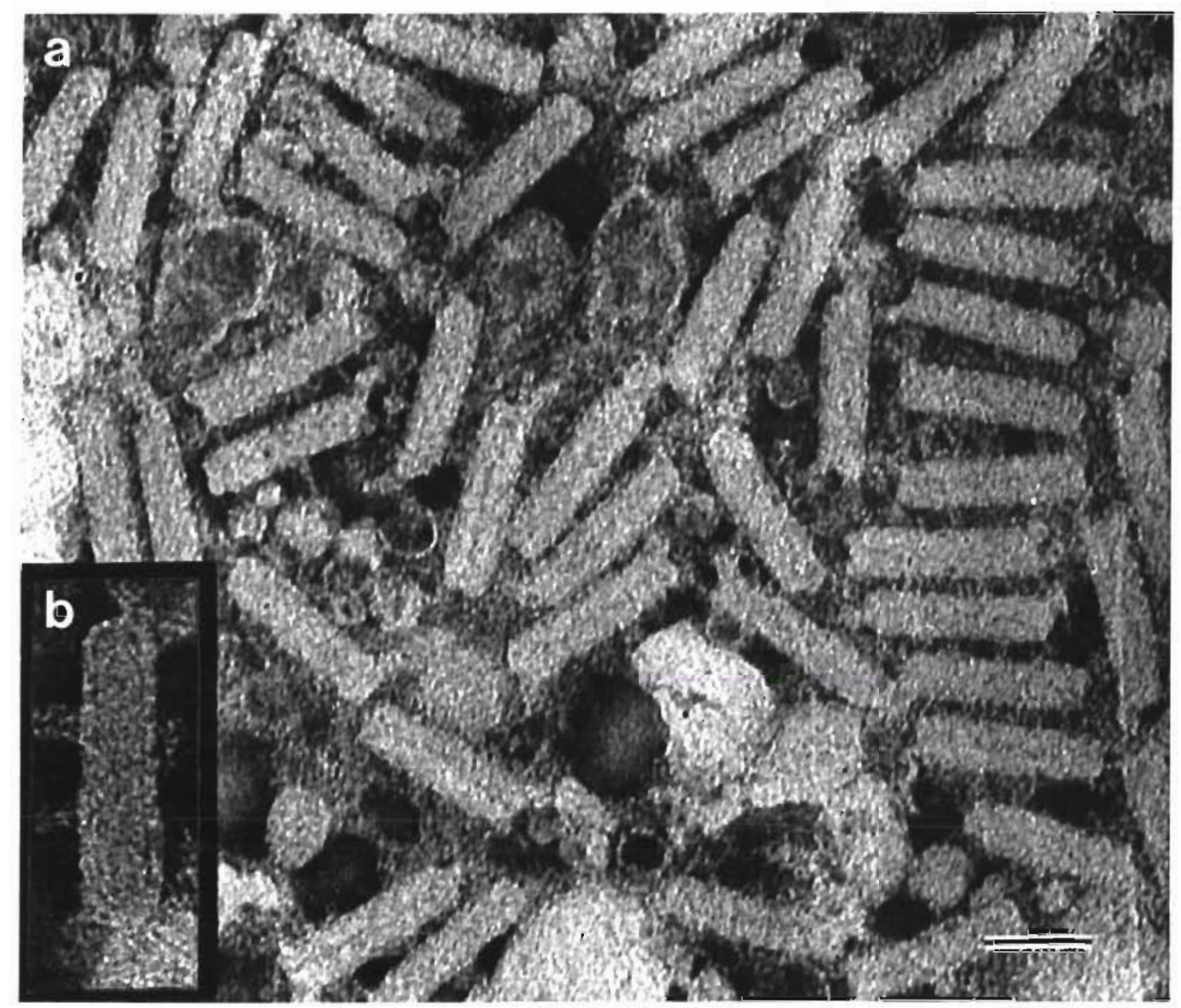

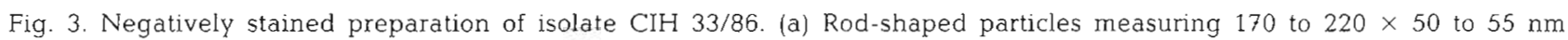
Ca $132000 x_{i}$ scale bar $=100 \mathrm{~nm}$. (b) Virus particles with an envelope. Ca $210000 \times$ 


\section{DISCUSSION}

Of the 55 families of viruses recognized by the International Comittee on Taxonomy of Viruses (ICTV) there are 20 families of animal viruses listed (Fields 1985). The classification of viruses is determined on the basis of nucleic acid, presence or absence of an envelope, and morphology. However, the grass carp virus does not fit into any of the recognized families of RNA-viruses because of its morphology and CPE-type. Some features determined for the isolate, e.g. its rodshaped morphology, lipid-containing envelope, and RNA genome, share similarities with the Rhabdoviridae. However, the ability to produce syncytia in vitro is not a common property of the rhabdoviruses. All rhabdoviruses investigated so far have proved to be distinct in morphology and serology from the isolate. Furthermore, the agent described differs clearly from the 2 viruses previously found in grass carp (Ahne 1975, Chen \& Jiang 1984).

Weiss \& Horzinek (1987) described pleomorphic RNA viruses found in different mammals which could not be assigned to any known virus family. Besides elliptical and circular virions there were elongated viruses with rounded ends, or bacilliform particles with rod-like cores. The enveloped virions measuring 120 to $170 \times 35$ to $47 \mathrm{~nm}$ were provisionally named 'Toroviruses'. Some features determined for the virus isolated from grass carp, e.g. the RNA genome, rod or bacilliform morphology, lipid-containing envelope, and the size of the virions, are similar to those described for members of the 'torovirus family'. However, 'toroviruses' obviously do not have the ability to produce syncytia in vitro, a characteristic feature of the new virus from grass carp.
Among the families of viruses infecting invertebrates, the baculoviruses also show a bacilliform morphology. The baculoviruses are enveloped virions that measure 40 to $60 \times 200$ to $400 \mathrm{~nm}$ but their genome consists of a single molecule of DNA (Matthews 1982). For that reason, the isolate from grass carp cannot be regarded as a member of Baculoviridae.

This new virus should be of special interest to virologists and microbiologists working in fish culture because of its uncertain taxonomic status and because of concerns about its epizootiological significance.

Acknowledgements. Funds for this study were provided by the Commission of the European Communities, Contract No. TSD-A-290-D (B).

\section{LITERATURE CITED}

Ahne, W (1975). A rhabdovirus isolated from grass carp (Ctenopharyngodon idella Val.). Arch. Virol. 58:181-185

Ahne, W. (1981). Serological techniques currently used in fish virology. Develop. biol. Standard. 49: 3-27

Ahne, W., Neubert, W. J., Thomsen, I. (in press). Reptilian viruses: isolation of myxovirus-like particles from the snake Elaphe oxycephala. J. Vet. Med. Series B

Chen, Y., Jiang, Y (1984). Morphological and physico-chemical characterization of the hemorrhagic virus of grass carp. Kexue Tongbao 29: 832-835

Fields, B. N. (1985). Fields virology. Raven Press, New York

Matthews, R. E. F. (1982). Classification and nomenclature of viruses. Karger, Basel, p. 1-181

Reed, L. J., Muench, H. (1938). A simple method of estimating fifty percent end points. Am. J. Hygiene 27: 493-497

Rovozzo, G. C., Burke, C. N. (1973). A manual of basic virological techniques. Prentice-Hall, Englewood Cliffs, New Jersey, p. 1-279

Weiss, M., Horzinek, M. C. (1987). The proposed family Toroviridae: agents of enteric infections. Arch. Virol. 92: $1-15$ 